\title{
LHX1 wt Allele
}

National Cancer Institute

\section{Source}

National Cancer Institute. LHX1 wt Allele. NCI Thesaurus. Code C53010.

Human LHX1 wild-type allele is located in the vicinity of $17 q 12$ and is approximately $6 \mathrm{~kb}$ in length. This allele, which encodes LIM/homeobox 1 protein Lhx1, may play a role in the regulation of transcription by RNA polymerase II and the development of lymphoid and neural cells. 